\title{
EFEK LAMA WAKTU PEMBERIAN EKSTRAK ETANOL SELEDRI (Apium graveolens L.) TERHADAP PENCEGAHAN PENINGKATAN KADAR IL-1 $\beta$ PADA TIKUS MODEL ISCHEMIA-REPERFUSION INJURY
}

\section{Celery (Apium graveolens L.) Ethanol Extract in the Prevention of Increases Il-1 $\beta$ In Ischemia-Reperfusion Injury Rats Model}

\author{
Afifah $\left.^{1 *}\right)$ Khusnul Muflikha ${ }^{2}$, Viva Ratih Bening Ati ${ }^{1}$ \\ ${ }^{1}$ Departemen Farmakologi Fakultas Kedokteran Universitas Jenderal Soedirman, \\ Purwokerto, Jawa Tengah, Indonesia \\ ${ }^{2}$ Departemen Fisiologi Fakultas Kedokteran Universitas Jenderal Soedirman, \\ Purwokerto, Jawa Tengah, Indonesia \\ *)Alamat korespondensi: afifah2403@gmail.com
}

\begin{abstract}
Ischemia-reperfusion injury (IRI) is the condition that disrupted the blood supply to the organ followed by the restoration of blood flow. IRI in the kidneys promotes the inflammatory cascade. Interleukin$1 \beta$ (IL-1 $\beta$ ) belongs to the most powerful pro-inflammatory cytokine that released in the early phase of IRI. Prevention of inflammation is one of the strategies for reducing kidney damage due to IRI. Celery (Apium graveolens $L$ ) is a natural resource that reported has anti-inflammatory and antioxidant effects. This study aimed to investigate the effect of duration of the administration ethanol extract of celery on IL-1 1 level in the IRI rat model. Twenty-five rats male Sprague Dawley, 2-3 months old were divided into 5 groups: Sham operations ( $S O, n=5$ ), Ischemia-reperfusion (IR, $n=5$ ), celery $1000 \mathrm{mg} / \mathrm{kg} B W$ for 7 days before IR (IR7) (IR7, $n=5), 14$ days before IR (IRI4, $n=5), 28$ days before IR (IR28, $n=5)$. The IL-1 $\beta$ level was assessed using the ELISA. Data were analyzed using One-way ANOVA $(p<0.05)$. The results showed that the mean of IL-1 $\beta$ levels in the IR7 group $(5.99 \pm 4.28 \mathrm{ng} / \mathrm{L})$ and $R 14(4.68 \pm 2.64 \mathrm{ng} / \mathrm{L})$ were lower than IR group $(8.19 \pm 5.36 \mathrm{ng} / \mathrm{L})$, while the $R 28$ group $(9.05 \pm 4.38 \mathrm{ng} / \mathrm{L})$ was higher than the IR group $(8.19 \pm 5.36 \mathrm{ng} / \mathrm{L})$. In conclusion, the administration of celery ethanol extract $1000 \mathrm{mg} / \mathrm{kg} \mathrm{BW}$ for 7 days and 14 days can prevent the increase of $I L-1 \beta$ level in the IRI rat model.
\end{abstract}

Key words: Apium graveolens L., celery, ischemia-reperfusion injury, IL-1 $\beta$.

\begin{abstract}
ABSTRAK
Ischemia-reperfusion injury (IRI) adalah suatu keadaan yang terjadi ketika suplai darah sebagian atau seluruh organ terganggu diikuti pemulihan aliran darah. IRI pada ginjal memicu terjadinya inflamasi. Interleukin-1 $\beta$ (IL-1 $\beta$ ) termasuk sitokin pro-inflamasi paling kuat yang keluar selama fase awal IRI. Pencegahan terhadap inflamasi merupakan strategi untuk menurunkan kerusakan ginjal akibat IRI. Seledri merupakan salah satu bahan alam yang diketahui mempunyai efek antiiflamasi dan antioksidan. Penelitian ini bertujuan mengetahui efek lama waktu pemberian ekstrak etanol seledri terhadap pencegahan peningkatan kadar IL-1 $\beta$ pada tikus model IRI. Sebanyak 25 ekor tikus jantan Sprague Dawley, 2-3 bulan, dikelompokkan menjadi 5, yaitu Sham Operation (SO, n=5), Ischemia-reperfusion (IR, n=5), seledri $1000 \mathrm{mg} / \mathrm{kgBB}$ selama 7 hari sebelum IR(IR7, n=5), 14 hari sebelum IR(IR14, n=5), dan 28 hari sebelum IR(IR28, n=5). Kadar IL-1 $\beta$ diukur menggunakan metode ELISA. Data dianalisis dengan One Way ANOVA ( $<<0,05)$. Rerata kadar IL-1 $\beta$ pada kelompok IR7 (5,99 $\pm 4,28 \mathrm{ng} / \mathrm{L})$ dan IR14 $(4,68 \pm 2,64 \mathrm{ng} / \mathrm{L})$ lebih rendah dibandingkan dengan kelompok IR $(8,19 \pm 5,36 \mathrm{ng} / \mathrm{L})$, sedangkan kelompok IR28 $(9,05 \pm 4,38 \mathrm{ng} / \mathrm{L})$ lebih tinggi dibandingkan dengan kelompok IR $(8,19 \pm 5,36 \mathrm{ng} / \mathrm{L})$. Pemberian ekstrak etanol seledri $1000 \mathrm{mg} / \mathrm{kgBB}$ selama 7 hari dan 14 hari dapat mencegah peningkatan kadar IL-1 $\beta$ pada tikus model IRI.
\end{abstract}

Kata kunci: Apium graveolens L., ischemia reperfusion injury, IL-1 $\beta$, seledri. 


\section{PENDAHULUAN}

Ischemia-reperfusion injury (IRI) adalah suatu keadaan yang terjadi ketika suplai darah sebagian atau seluruh organ terganggu diikuti oleh pemulihan aliran darah kembali. Kondisi IRI dapat terjadi setelah infark, sepsis, dan transplantasi organ. Pada ginjal, IRI dapat disebabkan oleh henti jantung (hipoperfusi sistemik), syok, intervensi bedah yang mengarah ke hipoperfusi ginjal seperti aortic crossclamping, nefrektomi parsial, dan transplantasi (Chatauret et al., 2014; Malek dan Nematbakhsh, 2015). IRI merupakan penyebab tersering acute kidney injury (AKI).

IRI pada ginjal memicu kaskade inflamasi dan semakin parahnya kerusakan ginjal. Inflamasi memiliki peran utama pada patofisiologi AKI akibat iskemia (Bonventre dan Zuk, 2004). Sel mast dan makrofag menghasilkan reactive oxygen species (ROS) yang menyebabkan aktivasi sel endotel dan selanjutnya sel endotel mengekspresikan berbagai kemokin sdan molekul adesi dan menyebabkan akumulasi leukosit pada tempat terjadinya cedera (Rusai et al., 2008).

Kemokin merupakan mediator utama pada inflamasi yang meregulasi sitokin proinflamasi, ekspresi molekul adesi, aktivasi dan infiltrasi leukosit
(Malek dan Nematbakhsh, 2015). Selain kontribusi leukosit dan sel endotel terhadap respon inflamasi akibat cedera iskemik, epitel tubulus ginjal juga menghasilkan mediator yang mempotensiasi inflamasi, antara lain yaitu tumor necrosis factor- $\alpha$ (TNF- $\alpha$ ), interleukin-6 (IL-6), interleukin-1 $\beta$ (IL$1 \beta)$ dan transforming growth factor- $\beta$ (TGF- $\beta$ ) (Bonventre dan Zuk, 2004).

IL-1 $\beta$ termasuk kelompok sitokin pro-inflamasi paling kuat yang keluar selama fase awal reperfusi setelah iskemia. IL-1 $\beta$ dapat memicu apoptosis dan proses inflamasi. Selanjutnya inflamasi diregulasi oleh molekul adesi yang memperantarai infiltrasi leukosit ke jaringan yang mengalami cedera. Ekspresi IL-1 $\beta$ pada ginjal mencapai kadar tertinggi yaitu 24 jam setelah induksi iskemia (Rusai et al., 2008). Strategi pencegahan terhadap inflamasi merupakan salah satu strategi untuk menurunkan tingkat kerusakan pada ginjal akibat IRI.

Upaya pencegahan menggunakan bahan alam merupakan salah satu potensi yang dapat dilakukan mengingat Indonesia merupakan negara yang kaya bahan alam. Seledri merupakan salah satu bahan alam yang banyak kita temukan di sekitar kita dan selama ini banyak dimanfaatkan masyarakat sebagai bahan makanan. Tanaman seledri diketahui 
mempunyai efek farmakologi yaitu sebagai antinflamasi (Taylor et al., 2012; Wulandari et al., 2016), antioksidan (Kooti dan Daraei, 2017; Sameh et al., 2011), antihipertensi (Kooti et al., 2014). Penelitian Afifah et al., (2019) menunjukkan bahwa ekstrak etanol seledri dosis $1000 \mathrm{mg} / \mathrm{kg}$ BB dapat mencegah kerusakan ginjal akibat IRI. Hingga saat ini belum ada penelitian yang meneliti efek lama waktu pemberian ekstrak etanol seledri terhadap pencegahan peningkatan kadar IL-1 $\beta$ pada tikus model IRI Penelitian ini bertujuan untuk mengetahui efek lama waktu pemberian ekstrak etanol seledri terhadap pencegahan peningkatan kadar IL-1 $\beta$ pada tikus model IRI.

\section{METODE}

Penelitian ini merupakan penelitian kuasi eksperimental dengan rancangan posttest only controlled group design. Penelitian ini dilakukan di Laboratorium Farmakologi dan Laboratorium Riset Fakultas Kedokteran, Universitas Jenderal Soedirman. Penelitian ini sudah mendapatkan ethical clerance dari Komisi Etik Fakultas Kedokteran, Universitas Jenderal Soedirman tanggal 5 Juli 2019 dengan nomor 3052/KEPK/VII/2019.

\section{Alat dan Bahan}

Alat yang digunakan pada penelitian ini yaitu kandang hewan coba, timbangan digital, skala 0-2000 gram merk Sweet Scale Oxone OX-211 diproduksi oleh PT Oxone Indonesia, timbangan digital, skala 0,00000100,0000 gram merk Dragon 303 Precision Balance-AAR 3231 diproduksi Mettler Toledo Group, spidol snowman permanent marker warna hitam, bulldock klem, minor set, sonde oral nomor $18 \mathrm{G}$ stainless steel dengan ball tripped needle, sarung tangan, spuit $3 \mathrm{cc}$, gelas kimia, labu erlenmeyer, batang pengaduk, gelar ukur $100 \mathrm{cc}$, mikropipet $100 \mu \mathrm{l}$ Fit merk Accumax pro diproduksi PT Endo Indonesia, mikropipet $1000 \mu \mathrm{l}$ Fit merk Accumax pro diproduksi PT Endo Indonesia, tabung EDTA, tabung eppendorf, rak tabung reaksi, Laboratory Centrifuge Lab Medical Practice 2000$4000 \mathrm{rpm}$, ELISA reader 450nm, spektofotometer. Bahan yang digunakan pada penelitian ini yaitu seledri, yang diperoleh dari Pratin, Purbalingga, etanol 96\%, ketamine, aquades, ELISA kit.

\section{Subjek Penelitian}

Sebanyak 25 ekor tikus putih jantan Sprague Dawley, BB 190-250 gram, usia 2-3 bulan digunakan sebagai subjek pada penelitian ini. Hewan coba dimasukkan ke dalam kandang dan dijaga 
pada suhu $25^{\circ} \mathrm{C}$, dengan siklus gelap terang 12jam/12 jam. Hewan coba di aklimatisasi selama 7 hari, dan akses makan serta minum secara ad libitum.

\section{Ekstraksi Tamanan}

Seledri didapatkan dari Pratin, Purbalingga, Jawa Tengah dan diidentifikasi di Laboratorium Lingkungan, Fakultas Biologi, Universitas Jenderal Soedirman. Pembuatan ekstrak etanol tanaman seledri dilakukan dengan cara maserasi. Tanaman seledri dipotong dan dikeringkan dalam oven pengering suhu $45^{\circ} \mathrm{C}$ kemudian digiling dengan mesin diskmill, dengan ayakan 60 mesh. Serbuk simplisia dimasukkan ke dalam kontainer ekstraktor dan ditambahkan etanol 70\%. Ekstraksi dengan ultraturax kecepatan $1.000 \mathrm{rpm}$, dan dimaserasi selama 24 jam. Selanjutnya difiltrasi menggunakan corong Buchner, dan disedot dengan mesin vakum. Filtrat dievaporasi dengan vacuum rotary evaporator tekanan vakum pada suhu $45^{\circ} \mathrm{C}$ kecepatan rotary $90 \mathrm{rpm}$. Ekstrak dipindahkan ke dalam cawan porselin kemudian dimasukkan ke dalam oven digital pada suhu $45^{\circ} \mathrm{C}$. Ekstrak dikeringkan hingga bobot tetap.

\section{Perlakuan hewan coba}

Hewan coba dikelompokkan secara acak menjadi 5 kelompok perlakuan dengan masing-masing kelompok terdiri dari 5 ekor. Setiap kelompok hewan coba diberikan perlakuan sebagai berikut: Kelompok SO: Hewan coba dengan Sham Operation; Kelompok IR: Hewan coba dengan IRI; Kelompok IR7: Hewan coba diberi ekstrak etanol seledri dosis 1000 $\mathrm{mg} / \mathrm{kgBB}$ selama 7 hari kemudian dibuat model IRI dan dan tikus diterminasi pada hari berikutnya; Kelompok IR14: Hewan coba diberi ekstrak etanol seledri dosis $1000 \mathrm{mg} / \mathrm{kgBB}$ selama 14 hari kemudian dibuat model IRI dan dan tikus diterminasi pada hari berikutnya; Kelompok IR28: Hewan coba diberi ekstrak etanol seledri dosis $1000 \mathrm{mg} / \mathrm{kgBB}$ selama 28 hari kemudian dibuat model IRI dan tikus diterminasi pada hari berikutnya.

\section{Pembuatan model IRI}

Tikus dianestesi menggunakan ketamin (dosis $100 \mathrm{mg} / \mathrm{kgBB}$ ) dengan suntikan intra muskuler. Perut tikus dibedah pada pertengahan (linea mediana) dan hilus renalis kanan dan kiri dijepit dengan menggunakan non-traumatic vascular clamp selama 45 menit. Perut tikus kemudian ditutup dengan dijahit menggunakan benang jahit. Pada kelompok SO dilakukan prosedur yang sama kecuali clamp hilus renalis. Tikus dikembalikan ke kandang. 


\section{Pengambilan sampel darah}

Hewan coba diambil darahnya sebanyak $3 \mathrm{ml}$ melalui sinus retroorbitalis. Darah (whole blood) disentrifugasi 4000 rpm selama 10 menit untuk mendapatkan serum, serum yang terbentuk kemudian dipindahkan ke tabung eppendorf.

\section{Pengukuran kadar IL-1 $\beta$}

Pengukuran kadar IL-1 $\beta$ dilakukan dengan menambahkan $50 \mu \mathrm{L}$ standar ke standar well. Menambahkan $40 \mu \mathrm{L}$ serum sempel ke sampel well, kemudian menambahkan $10 \mu \mathrm{L}$ anti IL-1 $\beta$ antibodi ke sampel. Menambahkan $50 \mu \mathrm{L}$ streptavidin HRP ke sampel well dan standar well, campur merata, tutup plate dengan sealer, inkubasi 60 menit pada suhu $37^{\circ} \mathrm{C}$. Buang sealer dan cuci plate sebanyak 5 kali dengan wash buffer. Menambahkan $50 \mu \mathrm{L}$ substrat solution A pada masing-masing well, kemudian menambahkan $50 \mu \mathrm{L}$ substrat solution B ke masing-masing well. Inkubasi plate selama 10 menit pada suhu $37^{\circ} \mathrm{C}$ di dalam gelap. Menambahkan $50 \mu \mathrm{L}$ stop solution pada masing-masing well. Warna biru akan berubah menjadi kuning. Pembacaan dilakukan dengan ELISA reader dengan panjang gelombang $450 \mathrm{~nm}$ maksimal 10 menit setelah penambahan stop solution.
Kadar IL-1 $\beta$ serum sampel darah tikus dinyatakan dengan satuan ng/L.

\section{Analisis statistik}

Data disajikan dalam bentuk tabel dan grafik. Analisis statistik yang digunakan yaitu One-Way ANOVA dengan melakukan uji normalitas dan homogenitas terlebih dahulu. Uji normalitas menggunakan Saphiro-wilk dan homogenitas menggunakan Levene's test. Nilai $\mathrm{p}<0,05$ digunakan sebagai kriteria signifikansi.

\section{HASIL DAN PEMBAHASAN}

Penelitian quasi eksperimental ini bertujuan untuk mengetahui efek lama waktu pemberian ekstrak etanol seledri terhadap kadar IL-1 $\beta$ pada tikus model IRI. Penelitian dilaksanakan di Laboratorium Farmakologi Fakultas Kedokteran, Universitas Jenderal Soedirman dan Laboratorium Riset Fakultas Kedokteran, Universitas Jenderal Soedirman

Hasil penelitian menunjukkan bahwa rerata kadar IL-1 $\beta$ pada kelompok SO $(4,79 \pm 3,48 \mathrm{ng} / \mathrm{L})$, IR $(8,19 \pm 5,36$ ng/L), IR7 (5,99 \pm 4,28 ng/L), IR14 (4,68 $\pm 2,64 \mathrm{ng} / \mathrm{L})$, dan IR28 (9,05 $\pm 4,38 \mathrm{ng} / \mathrm{L})$. Setelah dilakukan uji normalitas menggunakan uji Saphiro-wilk dan uji homogenitas menggunakan Leven's test 
diperoleh bahwa sebaran data normal dengan nilai $p=0,73 \quad(p>0,05)$ dan homogen dengan nilai $p=0,628(p>0,05)$. Karena data normal dan homogen selanjutnya dilakukan uji statistik one way ANOVA. Hasil uji one way ANOVA didapatkan $\quad p$-value $=0,357 \quad(\mathrm{p}>0,05)$ (Tabel 1). Hal itu menunjukkan bahwa tidak terdapat perbedaan yang bermakna rerata kadar IL-1 $\beta$ antar kelompok.

Tabel 1. Hasil analisis statistik uji one way ANOVA kadar IL-1ß

\begin{tabular}{llll}
\hline Kelompok & n & Mean \pm SD & p-value \\
\hline SO & 5 & $4,79 \pm 3,48$ & 0,357 \\
IR & 5 & $8,19 \pm 5,36$ & \\
IR7 & 5 & $5,99 \pm 4,28$ & \\
IR14 & 5 & $4,68 \pm 2,64$ & \\
IR28 & 5 & $9,05 \pm 4,38$ &
\end{tabular}

Keterangan:Kelompok SO: sham operation; Kelompok IR: ischemia-reperfusion injury; Kelompok IR7: diberi ekstrak etanol seledri $1000 \mathrm{mg} / \mathrm{kgBB}$ selama 7 hari kemudian dibuat IRI; Kelompok IR14: diberi ekstrak etanol seledri $1000 \mathrm{mg} / \mathrm{kgBB}$ selama 14 hari kemudian dibuat IRI; Kelompok IR28: diberi ekstrak etanol seledri $1000 \mathrm{mg} / \mathrm{kgBB}$ selama 28 hari kemudian dibuat IRI.

Rerata kadar IL-1 $\beta$ pada setiap kelompok dapat dilihat pada Gambar 1. Rerata kadar IL-1 $\beta$ pada kelompok IR $(8,19 \mathrm{ng} / \mathrm{L})$ lebih tinggi dibandingkan dengan kelompok SO (4,79 ng/L). Meskipun berdasarkan hasil analisis statistik tidak berbeda bermakna tetapi dapat dilihat bahwa pada kelompok IR, yaitu kelompok yang dilakukan klem pada hilus renalis untuk membuat aliran darah ke ginjal berhenti selama 45 menit dan kemudian klem dilepas sehingga darah kembali mengalir, kadarnya lebih tinggi dibandingkan dengan kelompok SO, yaitu kelompok yang tidak dilakukan klem pada hilus renalis. Sesuai dengan penelitian $\mathrm{Wu}$ et al. (2007) yang menunjukkan bahwa terjadi peningkatan kadar IL-1 $\beta$ yang signifikan pada ginjal dengan IRI dibandingkan dengan kelompok kontrol sham (Wu et al., 2007). Menurut Joe et al. (2006) ekspresi IL-1 pada ginjal mencapai puncak tertinggi pada 24 jam setelah induksi ischemia (Jo et al., 2006).

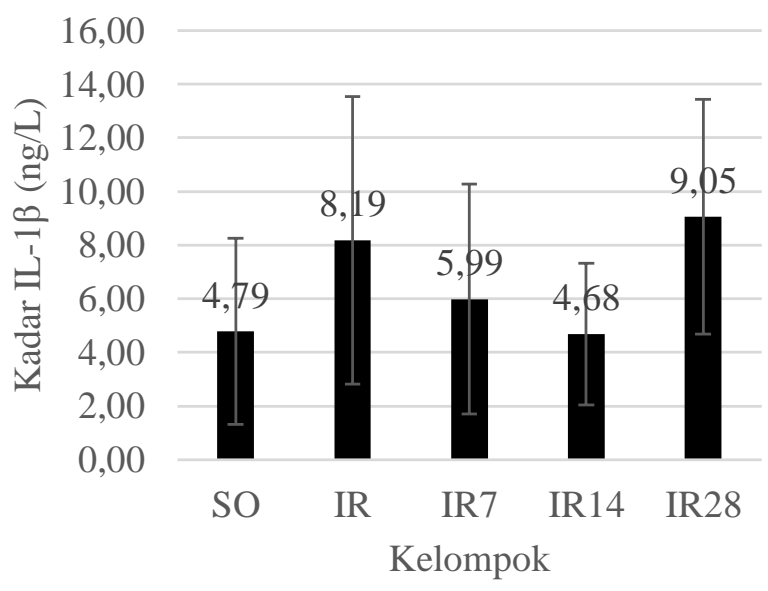

Gambar 1. Rerata kadar IL-1 $\beta$

Kadar IL-1 $\beta$ pada kelompok IR7 (kelompok yang diberi ekstrak etanol seledri dosis $1000 \mathrm{mg} / \mathrm{kgBB}$ selama 7 hari) sebesar 5,99 ng/L dan kadar IL-1 $\beta$ pada kelompok IR14 (kelompok yang diberi ekstrak etanol seledri dosis 1000 $\mathrm{mg} / \mathrm{kgBB}$ selama 14 hari) sebesar 4,68 ng/L sedangkan pada kelompok IR28 (kelompok yang diberi ekstrak etanol 
seledri dosis $1000 \mathrm{mg} / \mathrm{kgBB}$ selama 28 hari) sebesar 9,05 ng/L. Kelompok IR7 dan IR14 memiliki kadar IL-1 $\beta$ yang lebih rendah dibandingkan dengan kelompok IR. Kelompok yang diberikan ekstrak seledri selama 14 hari kemudian dibuat model IRI memiliki kadar IL-1 $\beta$ lebih rendah dibandingkan dengan kelompok yang diberi ekstrak etanol seledri selama 7 hari. Ekstrak daun dan batang seledri mengandung fenol. Flavonoid merupakan komponen utama yang mengandung epigenin. Efek antiinflamasi flavonoid pada seledri kemungkinan melalui jalur

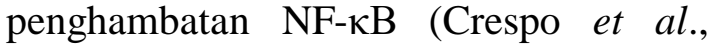
2008). NF- $\kappa B$ merupakan regulator inflamasi (Bhakar et al., 2002). NF-кB bertahan dalam bentuk laten di sitoplasma sel terikat dengan protein inhibitori $\mathrm{I} \kappa \mathrm{B}$. Kompleks enzim I $\mathrm{KB}$ kinase (IKK) bertanggungjawab dalam fosforilasi IкB. Fosforilasi IкB tersebut akan melepaskan NF-кB. Aktivasi IKK penting untuk menginduksi aktivitas NF- $\kappa \mathrm{B}$ (Ridder dan Schwaninger, 2009). Di endotel, NF-кB memicu ekspresi cellular adhesion molecules (CAM) dan sitokin proinflamasi yang menginduksi migrasi leukosit (Godínez-Rubí et al., 2013). Flavonoid akan menurunkan aktivitas NF$\kappa \mathrm{B}$ dengan mencegah degradasi dari inhibitor I $\mathrm{KB}$ dan mencegah aktivasi extracellular signal-regulated kinases
(ERK) (Crespo et al., 2008). Aktivitas NF$\kappa \mathrm{B}$ yang menurun akan mencegah kerusakan endotel. Seledri juga mengandung tannin yang berperan sebagai scavenger radikal bebas yang terbentuk akibat cedera iskemia reperfusi (Karamacì, 2009). Adanya pembentukan radikal bebad pada tikus model IRI juga memicu terjadinya inflamasi. Sesuai penelitian Afifah et al. (2019) pemberian ekstrak etanol seledri dapat mencegah penurunan kadar SOD pada tikus model IRI (Afifah et al., 2019), sehingga penurunan radikal bebas juga menurunkan inflamasi.

Berdasar hasil penelitian pada kelompok IR28, yaitu kelompok yang diberikan ekstrak etanol seledri selama 28 hari diperoleh kadar IL-1 $\beta$ sebesar 9,05 ng/L. Nilai tersebut lebih tinggi dibandingkan kelompok IR. Hal itu menunjukkan bahwa kemungkinan inflammasi yang terjadi lebih besar dibandingkan dengan kelompok IR. Kondisi tersebut diduga bahwa adanya kandungan seledri yang bersifat antioksidan jika dalam jumlah yang berlebih akan berbalik sifat menjadi prooksidan yang justru memperberat kerusakan pada IRI (Erejuwa et al., 2010), namun demikian perlu dilakukan penelitian lebih lanjut mengenai kadar oksidan pada model ini. 


\section{KESIMPULAN}

Berdasarkan hasil penelitian dapat disimpulkan bahwa pemberian ekstrak etanol seledri dosis $1000 \mathrm{mg} / \mathrm{kgBB}$ selama 7 hari dan 14 hari dapat mencegah peningkatan kadar IL-1 $\beta$ pada tikus model IRI. Implikasi hasil penelitian ini diharapakan ekstrak seledri dapat dikonsumsi pada populasi yang berisiko tinggi mengalami AKI sehingga diharapkan dapat mencegah inflamasi yang berlebihan jika terjadi AKI.

\section{UCAPAN TERIMA KASIH}

Terima kasih kepada Rektor Unsoed melalui LPPM Unsoed yang telah mendanai penelitian ini tahun anggaran 2019.

\section{DAFTAR PUSTAKA}

Afifah A, Muflikhah K, Ati VRB, Tsani RM, Khasanah D, Maulana W. 2019. Protective effect of ethanol extract of celery (Apium graveolens L) on kidney damage in ischemia/ reperfusion injury rats model. Molekul 14(1): 11-17. doi: 10.20884/1.jm.2019.14.1.448.

Bhakar AL, Tannis LL, Zeindler C, Russo M.P, Jobin C. Park DS, et al. 2002. Constitutive nuclear factor- $\kappa \mathrm{B}$ activity is required for central neuron survival. Journal of Neuroscience 22(19): 8466-8475. doi: 10.1523/jneurosci.22-19-08466.2002.

Bonventre JV dan Zuk A. 2004. Ischemic acute renal failure: An inflammatory disease? Kidney International 66: 480-485. doi: 10.1111/j.1523-1755.2004.761_2.x.

Chatauret N, Badet L, Barrou B, Hauet T. 2014).
Ischemia-reperfusion: From cell biology to acute kidney injury. Progres En Urologie 24(SUPPL.1): S4-S12. doi: 10.1016/S11667087(14)70057-0.

Crespo I, García-Mediavilla MV, Gutiérrez B, Sánchez-Campos S, Tuñón MJ, GonzálezGallego J. 2008. A comparison of the effects of kaempferol and quercetin on cytokineinduced pro-inflammatory status of cultured human endothelial cells. British Journal of Nutrition 100(5): 968-976. https://doi.org/10.1017/S000711450896608 3.

Erejuwa OO, Sulaiman SA, Wahab MSA, Sirajudeen KNS, Md Salleh MS, Gurtu S. 2010. Antioxidant protective effect of glibenclamide and metformin in combination with honey in pancreas of streptozotocin- induced diabetic rats. International Journal of Molecular Sciences 11(5): 2056-2066. doi: 10.3390/ijms 11052056 .

Godínez-Rubí M., Rojas-Mayorquín AE, OrtuñoSahagún D. 2013. Nitric oxide donors as neuroprotective agents after an ischemic stroke-related inflammatory reaction. Oxidative Medicine and Cellular Longevity 2013. doi: 10.1155/2013/297357.

Jo SK, Sung SA, Cho WY, Go KJ, Kim H K. 2006. Macrophages contribute to the initiation of ischaemic acute renal failure in rats. Nephrology Dialysis Transplantation 21(5): 1231-1239. doi: 10.1093/ndt/gfk047.

KaramacI M. 2009. In-vitro study on the efficacy of tannin fractions of edible nuts as antioxidants. European Journal of Lipid Science and Technology 111(11): 10631071. doi: 10.1002/ejlt.200900067.

Kooti W, Ali-akbari S, Asadi-samani M, Ghadery H, Ashtary-larky D. 2014. A review on medicinal plant of Apium graveolens. Advanced Herbal Medicine 1(1): 48-59.

Kooti W dan Daraei N. 2017. A Review of the Antioxidant Activity of Celery (Apium graveolens L). Journal of Evidence-Based Complementary and Alternative Medicine 22(4): $1029-1034 . \quad$ doi: $10.1177 / 2156587217717415$.

Malek M dan Nematbakhsh M. 2015. Renal ischemia/reperfusion injury; from pathophysiology to treatment. Journal of 
Renal Injury Prevention 4(2): 20-27. doi: 10.12861/jrip.2015.06.

Ridder DA dan Schwaninger M. 2009. NF-кB signaling in cerebral ischemia. Neuroscience 158(3): 995-1006. doi: 10.1016/J.NEUROSCIENCE.2008.07.007.

Rusai K, Huang H, Sayed N, Strobl M, Roos M, Schmaderer, C. et al. 2008. Administration of interleukin-1 receptor antagonist ameliorates renal ischemia-reperfusion injury. Transplant International 21(6): 572580. doi: 10.1111/j.14322277.2008.00651.x.

Sameh B, Ibtissem B, Mahmoud A, Boukef K, Naceur A. 2011. Antioxidant Activity of Apium graveolens Extracts. Journal of Biologgically Active Product from Nature 1(5-6): 340-343. doi: 10.1080/22311866.2011.10719102.

Taylor P, Baananou S, Borgi W, Mahmoud A, Boukef K, Chouchane N. 2012. Antiinflammatory and Analgesic Activities of Tunisian Apium graveolens L . Leaves Extracts in Rats. Journal of Biologgically Active Product from Nature 4: 37-41. doi: 10.1080/22311866.2012.10719129.

Wu H, Chen G, Wyburn KR, Yin J, Bertolino P, Eris J. et al. 2007. TLR4 Activation Mediates Kidney Ischemia/Reperfusion Injury. The Journal of Clinical Investigation, 117: 2847-2859. doi: 10.1097/00007890200607152-00905.

Wulandari DI, Fitrianingsih SP, Mulqie L. 2016. Uji Aktivitas Antiinflamasi Ekstrak Etanol Herba Seledri ( Apium graveolens L .) terhadap Tikus Wistar Jantan. [Prosiding] Farmasi 2: 59-66. 